\title{
ASSESSMENT OF THE PROXIMITY OF DESIGN TO MINIMUM MATERIAL CAPACITY SOLUTION OF PROBLEM OF OPTIMIZATION OF THE FLANGE WIDTH OF I-SHAPED CROSS-SECTION RODS WITH ALLOWANCE FOR STABILITY CONSTRAINTS OR CONSTRAINTS FOR THE VALUE OF THE FIRST NATIONAL FREQUENCY AND STRENGTH REQUIREMENTS
}

\author{
Leonid S. Lyakhovich ${ }^{1}$, Pavel A. Akimov ${ }^{1,2,3}$, Boris A. Tukhfatullin ${ }^{1}$ \\ ${ }^{1}$ Tomsk State University of Architecture and Civil Engineering, Tomsk, RUSSIA \\ ${ }^{2}$ National Research Moscow State University of Civil Engineering, Moscow, RUSSIA \\ ${ }^{3}$ Peoples' Friendship University of Russia, Moscow, RUSSIA
}

\begin{abstract}
There are known methods for optimizing the flange width of I-shaped cross-section rods with stability constraints or the constraints for the value of the first natural frequency. Corresponding objective function has the form of the volume of the flange material for the case when only the flange width varies and the crosssection height, wall thickness and flange thickness are specified. Special criterion for assessment of proximity of corresponding an optimal solution to the design of minimal material capacity was formulated for the considering problem. In this case, the resulting solution may not meet some other unaccounted constraints, for example, strength requirements. Modification of solution in order to meet previously unaccounted constraints does not allow researcher to consider such design as optimal. In the distinctive paper allowance for strength requirements, stability constraints or constraints for the value of the first natural frequency are proposed within considering problem of optimization. Special approach is formulated, which proposes to assess proximity to the design of minimum of material capacity obtained as a result of optimization. Increment of the objective function and criteria corresponding to constrains and restrictions are under consideration within computational process.
\end{abstract}

Keywords: criterion, optimization, limitations, strength conditions, minimum material capacity, stability, frequency, critical force, forms of stability loss, forms of natural vibrations, reduced stresses

\section{ОЦЕНКА БЛИЗОСТИ К ПРОЕКТУ МИНИМАЛЬНОЙ МАТЕРИАЛОЕМКОСТИ РЕШЕНИЯ ОБ ОПТИМИЗАЦИИ ШИРИНЫ ПОЛОК СТЕРЖНЕЙ ДВУТАВРОВОГО СЕЧЕНИЯ ПРИ ОГРАНИЧЕНИЯХ ПО УСТОЙЧИВОСТИ ИЛИ ВЕЛИЧИНЫ ПЕРВОЙ ЧАСТОТЫ СОБСТВЕННЫХ КОЛЕБАНИЙ С УЧЁТОМ ТРЕБОВАНИЙ ПРОЧНОСТИ.}

\author{
Л.С. Ляхович ${ }^{1}$, П.А. Акимов ${ }^{1,2,3}$, Б.А. Тухффатуллин ${ }^{1}$ \\ ${ }^{1}$ Томский государственный архитектурно-строительный университет, г. Томск, РОССИЯ \\ ${ }^{2}$ Национальный исследовательский Московский государственный строительный университет, \\ г. Москва, РОССИЯ \\ ${ }^{3}$ Российский университет дружбы народов, г. Москва, РОССИЯ
}

\begin{abstract}
Аннотация: Известны методы оптимизации ширины полок стержней двутаврового поперечного сечения при ограничениях по устойчивости или величине первой частоты собственных колебаний, функции цели в виде объема материала полок, для случая, когда варьируется только ширина полок, а высота сечения, толщина стенки и толщина полки заданы. Для этого варианта постановки задачи был сформулирован критерий оценки близости такого оптимального решения к проекту минимальной материалоемкости.
\end{abstract}


При этом в полученном решении могут не выполняться некоторые другие неучтённые ограничения, например, по прочности. Изменение полученного решения с целью удовлетворения неучтённым ранее ограничениям не позволяет считать такой проект оптимальным. В данной статье предлагается в рассматриваемой задаче учитывать в процессе оптимизации при ограничениях по устойчивости или величине первой частоты собственных колебаний ещё и условии прочности. Формулируется подход, в котором предлагается для оценки близости к проекту минимальной материалоемкости решения, полученного в результате оптимизации, наряду с анализом в процессе вычислений изменений величины приращения функции цели, использовать ещё и критерии, характеризующие каждое из принятых ограничений.

Ключевые слова: критерий, оптимизация, ограничения, условия прочности, минимальная материалоемкость, устойчивость, частота; критическая сила, формы потери устойчивости, формы собственных колебаний, приведенные напряжения

Earlier [1], the problem of the optimal outline of the flange width of the I-shaped cross-section rod [2], [3] was considered with allowance for stability constraints or constraints for the value of the first natural frequency. Corresponding objective function was the volume of the material of the flanges for the case when only the flange width varies and the section height, wall thickness and flange thickness are specified. Besides, special criterion was formulated for the proximity of such a solution to the minimal material capacity solution [1]. Criteria of assessment of proximity of the optimized design to corresponding minimum material capacity solution have also been formulated in many papers dealing with structural design $[6,9]$ and strengthening of structures $[4,5,7,8]$. Some specific theoretical problems dealing with formulation of the criteria $[10,11,12,13]$ were also considered. At the same time, other constraints (for example, strength conditions) were not taken into account normally. Therefore, solutions obtained in such cases might not satisfy these constraints. However, if the obtained design (project) is modified so that restrictions not previously considered are fulfilled, then the modified design (project) cannot be considered as optimal. In the distinctive paper allowance for strength requirements, stability constraints or constraints for the value of the first natural frequency are proposed within considering problem of optimization of the flange width of I-shaped cross-section rods.

As is known, analysis of changes in the increments of the objective function is normally used within optimization methods [14]. However, there are cases when the objective function changes slightly at the computational stages but the optimal solution has not yet been obtained and the corresponding design (project) is noticeably different from the minimum material capacity solution.

We recommend application of criteria corresponding to considering constraints and analysis of changes in the increments of the objective function within optimization process for assessment of proximity of design to minimum material capacity solution.

Thus, the I-shaped cross-section rod is under consideration. The cross-section height $b_{1}$, wall thickness $\delta_{s t}$ and flange thickness $\delta_{p}$ are specified. Flange width along the length of the rod ( $x$ axis) $b_{2}(x)$ or $b_{2}[i]$ within discrete model of the rod varies (Figure 1).

It is necessary to find a function $b_{2}(x)$ that, together with the given parameters $\left(b_{1}, \delta_{s t}, \delta_{p}\right)$, determines a rod that satisfies the stability constraints or constraints for the value of the first natural frequency (as well as the strength requirements and structural constraints) and at the same time provide a minimum volume of material of flanges.

The objective function within considering formulation of the problem has the form

$$
V_{0}=2 \int_{0}^{l} b_{2}(x) \delta_{p} d x
$$

For discrete model including $n$ sections we have 

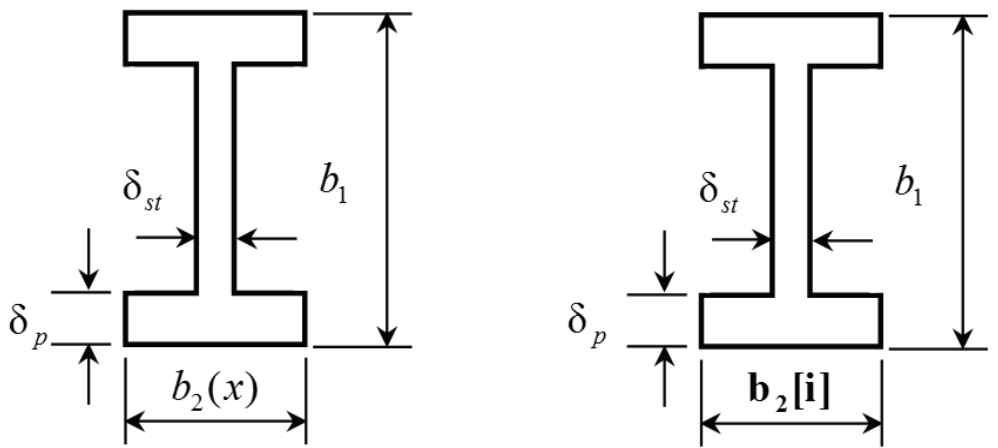

Figure 1. Considering cross-section of rods.

$$
\begin{aligned}
& \bar{\sigma}_{1 \omega t}(x)=\sqrt{\sigma_{1 \omega}^{2}(x) \cdot \frac{b_{1}}{2 \cdot \delta_{p}}-\sigma_{1 \omega t}^{2}(x) \cdot\left(\frac{b_{1}}{2 \cdot \delta_{p}}-1\right)-3 \cdot E \cdot\left(\omega_{0}\right)^{2} \cdot v_{\omega}^{2}(x) \cdot \rho}=\text { const }, \\
& V_{0}=2 \frac{l}{n} \sum_{1}^{n} b_{2}[i] \delta_{p} \text {, }
\end{aligned}
$$

where $V_{0}$ is the volume of material of flanges; $l$ is the length of the rod.

Stability constraints have the form

$$
P \leq P_{k p}
$$

where $P$ is the acting force, $P_{k p}$ is the corresponding critical force.

Constraint for the value of the first natural frequency has the form

$$
\omega_{0} \leq \omega 1
$$

where $\omega_{0}$ is the given value, $\omega 1$ is the value of the first natural frequency of the system.

Special criterion for assessments of results of optimization of flange width with allowance for stability constraints or constraints for the value of the first natural frequency is also formulated by the authors for the case when the flange width varies continuously along the length of the rod. This criterion can be presented in the form of three variants (versions, options):

$$
\begin{aligned}
\bar{\sigma}_{1 \omega t}^{2}(x) & =\sigma_{1 \omega}^{2}(x) b_{1}-\sigma_{1 \omega t}^{2}(x)\left(b_{1}-2 \delta_{p}\right)- \\
& -3 E\left(\omega_{0}\right)^{2} \rho \cdot 2 \delta_{p} v_{\omega}^{2}(x)=\mathrm{const}
\end{aligned}
$$

where $\sigma_{1 \omega}(x)$ and $\sigma_{1 \omega t}(x)$ are respectively normal stresses in the extreme fibers of the Ishaped cross-section and in the fibers at the boundary of the wall and the flange, created by bending moments arising from loss of stability or natural vibrations; $v_{\omega}(x)$ are the coordinates of the form of loss of stability or natural vibrations.

The variant (7) of the formulation of criterion was introduced only in order to emphasize its association with the previously formulated criteria. Application of this variant of the criterion with allowance for constraints for the value of the lowest natural frequency can lead to negative values of sub-root expressions and to corresponding problems dealing with computational process at the initial stages of optimization.

In this connection one of the equivalent variants (5) or (6) will be used in the distinctive paper. Criteria (5), (6), (7) can be used in combination with stability constraints or constraints for the value of the first natural frequency. In case of stability constraints we should assume that $\omega_{0}=0$ in the expressions of the criterion.

Three strength conditions must be fulfilled for rods of I-shape cross-section [14].

Strength condition for normal stresses in extreme fibers has the following form: 


$$
\sigma(x) \leq R,
$$

where $\sigma$ is normal stresses from the load in the extreme fibers of the rod; $R$ is design strength of the material of construction.

The condition for the fourth theory of strength at the junction of the flange with the wall has the following form:

$$
\sigma_{e q}(x)=\sqrt{\sigma_{p}^{2}(x)+3 \tau_{p}^{2}(x)} \leq R,
$$

where $\sigma_{e q}(x), \sigma_{p}(x), \tau_{p}(x)$ are respectively equivalent, normal, and shear stresses from the load at the junction of the flange with the wall. The condition for the fourth theory of strength at the center of gravity of the section has the following form:

$$
\sigma_{\text {экв }}(x)=\sqrt{\sigma_{0}^{2}(x)+3 \tau_{0}^{2}(x)} \leq R,
$$

where $\sigma_{e q}(x), \sigma_{0}(x), \tau_{0}(x)$ are respectively equivalent, normal, and shear stresses from the load at the center of gravity of the cross section. Let us rewrite expressions (8), (9) and (10) in expanded form, reflecting in them the internal forces of the rod and the parameters of its cross section. Besides, let us introduce the following notation system: $M(x), Q(x), N(x)$ are respectively, bending moments, transverse and longitudinal forces in the corresponding crosssections of the rod.

Condition (8) will take the following form:

$$
\begin{aligned}
& \sigma(x)=\frac{N(x)}{b_{1} \cdot b_{2}(x)-\left(b_{1}-2 \delta_{p}\right) \cdot\left(b_{2}(x)-\delta_{s t}\right)}+ \\
& +\frac{6 M(x) \cdot b_{1}}{b_{2}(x) \cdot b_{1}^{3}-\left(b_{2}(x)-\delta_{s t}\right)\left(b_{1}-2 \delta_{p}\right)^{3}} \leq R
\end{aligned}
$$

Condition (9) will take the form:

$$
\begin{aligned}
& \sigma_{e q}(x)= \\
& =\left\{\begin{array}{l}
\frac{N(x)}{b_{1} \cdot b_{2}(x)-\left(b_{1}-2 \delta_{p}\right) \cdot\left(b_{2}(x)-\delta_{s t}\right)}+ \\
+\frac{12 M(x)}{b_{2}(x) \cdot b_{1}^{3}-\left(b_{2}(x)-\delta_{s t}\right)\left(b_{1}-2 \delta_{p}\right)^{3}} \times \\
\times\left(\frac{b_{1}}{2}-\delta_{p}\right)
\end{array}\right]^{2}+ \\
& \left.+3 \cdot\left[\frac{6 \cdot Q b_{2}(x) \delta_{p}\left(b_{1}-\delta_{p}\right)}{\left(b_{2}(x) b_{1}^{3}-\left(b_{2}(x)-\delta_{s t}\right)\left(b_{1}-2 \delta_{p}\right)^{3}\right) \delta_{s t}}\right]^{2}\right\}^{\frac{1}{2}} \leq R
\end{aligned}
$$

Condition (10) will take the form:

$\sigma_{e q}=\left\{\left[\frac{N(x)}{b_{1} b_{2}-\left(b_{1}-2 \delta_{p}\right)\left(b_{2}-\delta_{s t}\right)}\right]^{2}+\right.$

$+3 \cdot\left[\frac{Q(x) \cdot\left[\begin{array}{l}\frac{3 b_{2}(x) b_{1}^{2}}{2}- \\ -6\left(b_{2}(x)-\delta_{s t}\right)\left(\frac{b_{1}}{2}-\delta_{p}\right)^{2}\end{array}\right]}{\left[b_{2}(x) b_{1}^{3}-\left(b_{2}(x)-\delta_{s t}\right)\left(b_{1}-2 \delta_{p}\right)^{3}\right] \delta_{s t}}\right]^{\frac{1}{2}} \leq R$

Design restrictions have the following form:

$$
b_{2}(x) \geq b b
$$

where $b b$ is minimum flange width.

Within a discrete model of the rod, the corresponding coordinates of considering crosssection $((x))$ are replaced by the corresponding number of the model section ([i]).

In order to ensure uniformity of the use of criteria and restrictions for assessing the proximity of the resultant optimized design (project) to design of minimum of material capacity we should normalize criterion (4) (or (5)) and conditions (8), (9), (10) and (13) so that if performed in the form of equalities, they would take a value equal to unity. 
Assessment of the Proximity of Design to Minimum Material Capacity Solution of Problem of Optimization of the Flange Width of I-Shaped Cross-Section Rods with Allowance for Stability Constraints or Constraints for the Value of the First Natural Frequency and Strength Requirements

When normalizing criterion (5) (or (6)), bending moments (which, like mode shapes (natural modes) are determined with accuracy to a constant factor) are revealed by the form of loss of stability or the first natural mode. Stresses $\sigma_{1 \omega}(x), \sigma_{1 \omega t}(x)$ and $\bar{\sigma}_{1 \omega t}^{2}(x)$ are computed in accordance with these moments in crosssections. Then, the maximum value is selected among $\bar{\sigma}_{1 \omega t}^{2}(x)$ and the values of expression (5) (or (6)) are divided into it. Now, if the design (project) obtained as a result of optimization is the design of minimum material capacity, then the criterion takes the form

$$
\bar{\sigma}_{1 \omega t}^{2}(x)=1
$$

If constraints (8), (9) and (10) are also used within optimization process, then the criterion (15) must be applied only to those parts of the rod in which dependencies (8), (9) and (10) are fulfilled in the form strict inequalities.

Let us normalize constraint (7).

Dividing both sides of expression (7) by $R$ we obtain

$$
R 1(x)=\frac{\sigma(x)}{R} \leq 1
$$

We can similarly normalize constraints (8) and (9) and get

$$
\begin{aligned}
& R 2(x)=\frac{\sigma_{\text {экв }}(x)}{\mathrm{R}}=\frac{\sqrt{\sigma_{p}^{2}(x)+3 \tau_{p}^{2}(x)}}{R} \leq 1 ; \\
& R 3(X)=\frac{\sigma_{\text {экв }}(\mathrm{x})}{\mathrm{R}}=\frac{\sqrt{\sigma_{0}^{2}(x)+3 \tau_{0}^{2}(x)}}{R} \leq 1 .
\end{aligned}
$$

In order to normalize the constraint (14), we should divide put both parts of the expression (13) by $b_{2}(x)$ and rewrite this constraint in the form

$$
b b_{0}(x)=\frac{b b}{b_{2}(x)} \leq 1 .
$$

Let us explain that $\bar{\sigma}_{1 \omega t}^{2}(x), R 1(x), R 2(x)$, $R 3(x)$ и $b b_{0}(x)$ in (15), (16), (17), (18) are indicators of fulfillment of restrictions ((2) or (3)), (8), (9) (10) and (14).

Now, after normalizing all the restrictions used, the proximity to the design (project) of minimum material capacity of the design (project), obtained as a result of optimization with allowance for stability constraints (or constraints for the value of the first natural frequency), strength and structural constraints is determined by the proximity of at least one of indicators (15), (16), (17), (18) and (19) to unity in each crosssection.

Let us give an illustration of the assessment of the proximity of the solution of the considering problem to the project of minimal material consumption by an example.

\section{Sample.}

A rigidly restrained rod of an I-shape crosssection is under consideration (Figure 2). The span of the rod is equal to $l=12 \mathrm{~m}$. The height of the cross-section of the rod is equal to $b_{1}=0.16 \mathrm{~m}$. Wall thickness is equal to $b s t=0.01 \mathrm{~m}$. Flange thickness is equal to $b_{p}=0.014 \mathrm{~m}$. Flange width is equal to $b_{2}=0.12 \mathrm{~m}$. Besides, flange width is constant along the entire length of the rod. The modulus of elasticity of the material of the rod is equal to $E=206000000000 \mathrm{~N} / \mathrm{m}^{2}$. Its specific gravity is equal to $7850 \mathrm{~kg} / \mathrm{m}^{3}$. Volumetric weight is equal to $77008.5 \mathrm{~N} / \mathrm{m}^{3}$. Design strength is equal to $R=240000000 \mathrm{~N} / \mathrm{m}^{2}$.

The rod carries a uniformly distributed mass of intensity $m=400 \mathrm{~kg} / \mathrm{m}$. The same mass is an external load with intensity $q=3924 \mathrm{~N} / \mathrm{m}$.

Own weight of the rod are taken into account in optimization process with allowance for strength conditions.

The critical force (ultimate load) of the rod (without taking into account possible vibrational effects) is equal to $\mathrm{Pcr}=1118457 \mathrm{~N}$. 


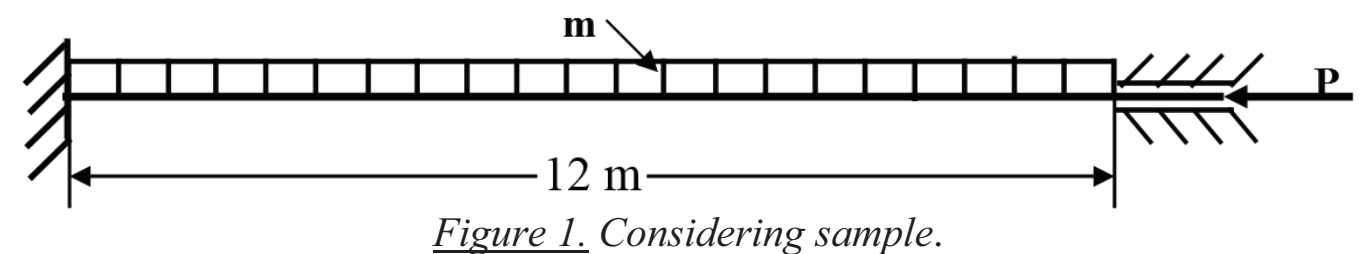

The first natural frequency (without taking into account the influence of the longitudinal force on the frequency) is equal to $\omega=18.5773 \mathrm{sec}^{-1}$. Let the compressive force be $P=300000 \mathrm{~N}$. The flange width is equal to $b_{2}=0.12 m$ (it is the same along its entire length of the rod). The first natural frequency of the rod with allowance for the influence of the longitudinal force on the frequency is equal to $\omega=12.9291 \mathrm{sec}^{-1}$. It should be noted that strength conditions were not considered within determination of the critical force and frequency.

Thus, in the considering sample it is required to optimize the shape of the width of the flanges of the considering rod loaded by $P=300000 \mathrm{~N}$, provide special value of the first natural frequency $\left(\omega 1 \geq \omega_{0}=13 \mathrm{sec}^{-1}\right)$ and minimum volume of the material of the flanges. Constraints for the value of the first natural frequency (4), strength constraints (8), (9), (10) and structural constraints (10) must be taken into account within optimization process. Let $b b=0.01 \mathrm{~m}$ be the smallest possible flange width.

Discrete model of the rod including 30 sections (elements) is used for corresponding analysis. Evenly distributed mass and load are reduced to nodes. Besides, we have nodal masses $(m[i]=160 \mathrm{~kg})$ and loads $(\mathrm{q}[\mathrm{i}]=1569.6 \mathrm{~N})$ within this discrete model. The mass and weight of the structure are taken into account within the optimization process.

Generally optimization can be performed by one of the well-known methods (various modifications of method of descent, random search method and so on) $[16,17]$. The random search method is used in the considering sample.

After completion of the optimization process, we will evaluate the proximity of the obtained solution to the corresponding minimal material capacity solution.
First of all, in order to compare the design of minimum material consumption with other possible solutions, several options should be considered.

The first variant. Conventional solution is considered in which the minimum value for the flange width $\left(b_{2}\right)$ is determined, provided that it is the same along the entire length of the rod, but restrictions (4), (8), (9), (10) and (14) are accepted.

Table 1. Results of analysis.

\begin{tabular}{|c|c|c|c|c|}
\hline 1 & \multicolumn{3}{|c|}{ Flange width $b_{2}[i]$} & $\bar{\sigma}_{\omega}^{2}[i]$ \\
\hline$i$ & 2 & 3 & 4 & 5 \\
\hline 1 & 0.2070 & 0.1649 & 0.2070 & 0.9967 \\
\hline 2 & 0.1800 & 0.1421 & 0.1800 & 0.9970 \\
\hline 3 & 0.1515 & 0.1196 & 0.1514 & 0.9969 \\
\hline 4 & 0.1215 & 0.0975 & 0.1215 & 0.9969 \\
\hline 5 & 0.0903 & 0.0755 & 0.0903 & 0.9969 \\
\hline 6 & 0.0582 & 0.0534 & 0.0582 & 0.9976 \\
\hline 7 & 0.0300 & 0.0300 & 0.0254 & 1.0000 \\
\hline 8 & 0.0100 & 0.0100 & 0.0100 & 0.0339 \\
\hline 9 & 0.0279 & 0.0279 & 0.0131 & 0.9911 \\
\hline 10 & 0.0460 & 0.0460 & 0.0403 & 0.9968 \\
\hline 11 & 0.0633 & 0.0599 & 0.0633 & 0.9971 \\
\hline 12 & 0.0818 & 0.0707 & 0.0818 & 0.9972 \\
\hline 13 & 0.0958 & 0.0785 & 0.0958 & 0.9965 \\
\hline 14 & 0.1052 & 0.0837 & 0.1052 & 0.9966 \\
\hline 15 & 0.1098 & 0.0863 & 0.1098 & 0.9972 \\
\hline 16 & 0.1098 & 0.0863 & 0.1098 & 0.9972 \\
\hline 17 & 0.1052 & 0.0837 & 0.1052 & 0.9966 \\
\hline 18 & 0.0958 & 0.0785 & 0.0958 & 0.9965 \\
\hline 19 & 0.0818 & 0.0707 & 0.0818 & 0.9972 \\
\hline 20 & 0.0633 & 0.0599 & 0.0633 & 0.9971 \\
\hline 21 & 0.0460 & 0.0460 & 0.0403 & 0.9968 \\
\hline 22 & 0.0279 & 0.0279 & 0.0131 & 0.9911 \\
\hline 23 & 0.0100 & 0.0100 & 0.0100 & 0.0339 \\
\hline 24 & 0.0300 & 0.0300 & 0.0254 & 1.0000 \\
\hline 25 & 0.0584 & 0.0534 & 0.0582 & 0.9976 \\
\hline 26 & 0.0903 & 0.0755 & 0.0903 & 0.9969 \\
\hline
\end{tabular}


Assessment of the Proximity of Design to Minimum Material Capacity Solution of Problem of Optimization of the Flange Width of I-Shaped Cross-Section Rods with Allowance for Stability Constraints or Constraints for the Value of the First Natural Frequency and Strength Requirements

\begin{tabular}{|c|c|c|c|c|}
\hline$i$ & 2 & 3 & 4 & 5 \\
\hline 27 & 0.1215 & 0.0975 & 0.1215 & 0.9969 \\
\hline 28 & 0.1515 & 0.1196 & 0.1514 & 0.9969 \\
\hline 29 & 0.1800 & 0.1421 & 0.1800 & 0.9970 \\
\hline 30 & 0.2070 & 0.1649 & 0.2070 & 0.9967 \\
\hline
\end{tabular}

with allowance for corresponding constraints. Otherwise, with the constraints taken into account, the objective function is minimal within the limits of errors and the proximity of the indicators $\bar{\sigma}_{\omega}^{2}[i]$ to unity.

The third variant. In order to verify the fulfill-

This solution implements the flange width, which is equal to $b_{2}=0.1542 \mathrm{~m}$. Moreover, restriction (7) in sections 1 and 30 is fulfilled in the form of an equality, and in all other sections it is fulfilled in the form of inequalities. Constraints (9), (10) and (14) in all sections of the rod are fulfilled in the form of inequalities. Constraint (3) is fulfilled in the form of inequality as well.

In this connection the first natural frequency of the rod is equal to $\omega 1=14.89 \mathrm{sec}^{-1} \geq 13 \mathrm{sec}^{-1}$.

Thus, the minimum value of flange width $b_{2}=0.1542 m$ (it is constant along the entire length of the rod) is determined by the active fulfillment of the strength constraint (8) for sections 1 and 30 and the passive fulfillment of all other constraints. The volume of material of the flanges in the considering variant is equal to $V_{0}=0.05181 \mathrm{~m}^{3}$.

The second variant. Let us optimize the values $b_{2}[i](i=1,2, \ldots, 30)$, that vary in each section, but without taking into account the strength constraints (i.e. constraints (4) and (14)). The results of this optimization are shown in the fourth column of Table 1. The volume of material of the flanges in the considering variant is equal to $V_{0}=0.030309 \mathrm{~m}^{3}$. The fifth column shows the indicators (15) of the fulfillment of the constraint (4). In all sections except section number 8 and section number 23, they differ only by a fraction of a percent from unity. In section number 8 and section number 23 we have $b_{2}[i]=0.01 \mathrm{~m}$. Therefor in these sections the restriction (14) is fulfilled in the form of equality and corresponding indicators are equal to $b b_{0}[8]=1, b b[23]=1$. Thus, in all sections of the rod we have indicator, which is fairly close to unity. This circumstance allows researcher to consider the resultant design quite close to the design of minimum material capacity but only ment of the strength conditions for the design obtained in the second variant with the values $b_{2}[i]$ bending moments and shear forces were determined in accordance with the deformed pattern taking into account applied load $q=3924 N / m$, dead weight and the influence of the longitudinal force $P=300000 \mathrm{~N}$.

Then, using formulas (11), (12), (13), a value of $b_{2}[i]$ was determined for each section under which one of the conditions (11), (12), (13) is satisfied as equality, and remaining as inequalities. They determine the minimum permissible flange width $\left(b_{2}[i]\right)$, satisfying the strength conditions. These values of $b_{2}[i]$ are shown in the third column of Table 1 . Comparison of the values of $b_{2}[i]$ in the third column with the corresponding values in the fourth column 4 shows that strengths constraints are not fulfilled in sections with the following numbers: $7,9,10,21$, 22,24 . If in these sections the dimensions of the flange width are increased to the minimum permissible dimensions under the strength conditions, leaving the dimensions in the remaining sections unchanged, then we get the design presented in the second column of Table 1. The objective function for this design is equal to $V_{0}=0.030874 \mathrm{~m}^{3}$, the value of the first natural frequency is equal to $\omega=13.1103 \mathrm{sec}^{-1}$ (constraint (4) is fulfilled in the form of an inequality). In this connection, the subsequent fulfillment of constraints not taken into account within optimization process does not allow researcher to consider the solution as a design of minimal material capacity.

The fourth variant. Let us now optimize the values $b_{2}[i](i=1,2, . ., 30)$ with allowance for constraints (4), (8), (9), (10) and (14) (including strength constraints). The results of this analysis are presented in Table 2 .

Volume 16, Issue 2, 2020 
Table 2. Results of analysis.

\begin{tabular}{|c|c|c|c|c|c|c|}
\hline$i$ & $b_{2}[i]$ & $\bar{\sigma}_{\omega}^{2}[i]$ & $R 1[i]$ & $R 2[i]$ & $R 3[i]$ & $b b_{0}[i]$ \\
\hline 1 & 0.1995 & 0.9986 & 0.8276 & 0.7238 & 0.2218 & 0,050 \\
\hline 2 & 0.1727 & 0.9994 & 0.8249 & 0.7247 & 0.2387 & 0,058 \\
\hline 3 & 0.1444 & 0.9991 & 0.8308 & 0.7340 & 0.2635 & 0,069 \\
\hline 4 & 0.1147 & 0.9992 & 0.8500 & 0.7564 & 0.3012 & 0,087 \\
\hline 5 & 0.0837 & 0.9992 & 0.8905 & 0.8000 & 0.3614 & 0,119 \\
\hline 6 & 0.0518 & 1.0000 & 0.9701 & 0.8834 & 0.4668 & 0,193 \\
\hline 7 & 0.0254 & 0.7037 & 1.0000 & 0.9351 & 0.6276 & 0,394 \\
\hline 8 & 0.0100 & -0.0239 & 0.9243 & 0.9002 & 0.7920 & 1 \\
\hline 9 & 0.0321 & 0.4443 & 1.0000 & 0.9256 & 0.5726 & 0,312 \\
\hline 10 & 0.0498 & 0.8364 & 1.0000 & 0.9074 & 0.4679 & 0,201 \\
\hline 11 & 0.0675 & 0.9999 & 0.9571 & 0.8592 & 0.3948 & 0,148 \\
\hline 12 & 0.0859 & 0.9993 & 0.8933 & 0.7967 & 0.3391 & 0,116 \\
\hline 13 & 0.0998 & 0.9993 & 0.8560 & 0.7599 & 0.3058 & 0,100 \\
\hline 14 & 0.1091 & 0.9993 & 0.8349 & 0.7390 & 0.2865 & 0,092 \\
\hline 15 & 0.1138 & 0.9991 & 0.8251 & 0.7293 & 0.2775 & 0,088 \\
\hline 16 & 0.1138 & 0.9991 & 0.8251 & 0.7293 & 0.2775 & 0,088 \\
\hline 17 & 0.1091 & 0.9993 & 0.8349 & 0.7390 & 0.2865 & 0,092 \\
\hline 18 & 0.0998 & 0.9993 & 0.8560 & 0.7599 & 0.3058 & 0,100 \\
\hline 19 & 0.0859 & 0.9993 & 0.8933 & 0.7967 & 0.3391 & 0,116 \\
\hline 20 & 0.0675 & 0.9999 & 0.9571 & 0.8592 & 0.3948 & 0,148 \\
\hline 21 & 0.0498 & 0.8364 & 1.0000 & 0.9074 & 0.4679 & 0,201 \\
\hline 22 & 0.0321 & 0.4443 & 1.0000 & 0.9256 & 0.5726 & 0,312 \\
\hline 23 & 0.0100 & -0.0239 & 0.9243 & 0.9002 & 0.7920 & 1 \\
\hline 24 & 0.0254 & 0.7037 & 1.0000 & 0.9351 & 0.6276 & 0,394 \\
\hline 25 & 0.0518 & 1.0000 & 0.9701 & 0.8834 & 0.4668 & 0,193 \\
\hline 26 & 0.0837 & 0.9992 & 0.8905 & 0.8000 & 0.3614 & 0,119 \\
\hline 27 & 0.1147 & 0.9992 & 0.8500 & 0.7564 & 0.3012 & 0,087 \\
\hline 28 & 0.1444 & 0.9991 & 0.8308 & 0.7340 & 0.2635 & 0,069 \\
\hline 29 & 0.1727 & 0.9994 & 0.8249 & 0.7247 & 0.2387 & 0,058 \\
\hline 30 & 0.1995 & 0.9986 & 0.8276 & 0.7238 & 0.2218 & 0,050 \\
\hline & & & & & \\
\hline
\end{tabular}

The second column shows the values of the flange width $b_{2}[i]$ within optimization process with allowance for considering constraints. The third column contains indicators (15) of the fulfillment of the constraint (4). In all sections (except sections with the following numbers: 7,8 , $9,10,21,22,23,24)$ they differ only by a small fraction of a percent from unity. In sections with numbers 7 and 23 we have $b_{2}[8]=0.01 \mathrm{~m}$ (i.e. in these sections, constraint (13) is fulfilled in the form of equality and indicators (15) are equal to $b b_{0}[8]=1$ and $b b_{0}[23]=1$. In sections with numbers $7,9,10,21,22,24$, indicators (16) of constraint (7) are equal to unity up to rounding. The remaining indicators (16) and (17) of strength constraints (9) and (10) are fulfilled in the form of inequalities (the sixth column and the seventh column). So, in each section, we revealed indicator which is quite close to unity in terms of the adopted set of constraints. This circumstance allows to consider resultant design (after corresponding optimization process with allowance for constraints for the value of the first natural frequency, strength constraints and structural constraints) as close, within the accepted errors, to the design of minimum material capacity (the second column of Table 2 . 
Assessment of the Proximity of Design to Minimum Material Capacity Solution of Problem of Optimization of the Flange Width of I-Shaped Cross-Section Rods with Allowance for Stability Constraints or Constraints for the Value of the First Natural Frequency and Strength Requirements

Table 3. Comparison of variants.

\begin{tabular}{|c|c|c|c|c|}
\hline & \multicolumn{4}{|c|}{ Variants } \\
\hline Number & 1 & 2 & 3 & 4 \\
\hline$V_{0}, m^{3}$ & $\mathbf{0 . 0 5 1 8 1}$ & $\mathbf{0 . 0 3 0 3 0 9}$ & $\mathbf{0 . 0 3 0 8 7 4}$ & $\mathbf{0 . 0 3 0 4 6 8}$ \\
\hline$\% \%$ & 0 & 41.50 & 40.41 & 41.20 \\
\hline$\omega 1, \mathrm{sec}^{-1}$ & $\mathbf{1 4 . 8 9}$ & 13 & $\mathbf{1 3 . 1 1 0 3}$ & 13 \\
\hline
\end{tabular}

In this variant the objective function is equal to $V_{0}=0.030468 \mathrm{~m}^{3}$.

A decrease in the value of the objective function is performed in comparison with the first variant. In the first and third variants, the constraint $\omega 1=13 \mathrm{sec}^{-1}$ is not reached, while the values of the objective function are greater than in the fourth variant, in which all constraints are fulfilled. In the second variant the objective function is less than in the fourth variant, but strength conditions are not fulfilled. A comparison of the variants confirms the feasibility of taking into account all the necessary constraints within optimization process (the fourth variant), and not after its completion (the third variant).

The solution closest to the design of minimal material capacity can be used in real design practice. We should note that normally it is impossible to formalize the full set of various constraints of the problem within the design of optimal systems. These are, for example, constraints dealing with technological requirements in the manufacture, transportation, installation, operation and disposal of an object, as well as many others.

An optimal design can perform various functions in real design practice. For example, a design of minimal material capacity can be considered as an idealized object. This function of such a design makes it possible to evaluate a real design solution by the criterion of its proximity to the limit (for example, by material capacity).

In addition, the optimal design can be used as a guideline for real design. Within this approach real design is considered as a phased process of moving away from an ideal object in order to fulfill the requirements (constraints) not considered in the optimal design.

In the distinctive paper we propose to use special criteria for assessment proximity of result- ant design after optimization process (computing flange with of I-shape cross-section of rod) with allowance for stability constraints, constraints for the value of the first natural frequency and structural constraints.

\section{ACKNOWLEDGEMENTS}

The distinctive research work was carried out at the expense of the State program of the Russian Federation "Scientific and technological development of the Russian Federation" and the Program for Fundamental Research of State Academies of Science for 2013-2020, as part of the Plan for Fundamental Scientific Research of the Ministry of Construction and Housing and Communal Services of the Russian Federation and the Russian Academy of Architecture and Construction Sciences for 2020, within science topic "Research and development of fundamental theoretical foundations of the synthesis of optimal structures as methods for designing structures with predetermined properties".

\section{REFERENCES}

1. Lyakhovich L.S. Osobye Svojstva Optimal'nyh Sistem i Osnovnye Napravlenija ih Realizacii v Metodah Rascheta Sooruzhenij [Special Properties of Optimal Systems and the Main Directions of Their Implementation in the Methods of Calculation of Structures]. Tomsk, Tomsk State University of Architecture and Construction, 2009, 372 pages (in Russian).

2. Li D., Paradowska A., Uy B., Wang J., Khan M. Residual stresses of box and Ishaped columns fabricated from S960 ultra- 
high-strength steel. // Journal of Constructional Steel Research, 2020, Volume 166, article 105904.

3. Xiao Y., Bie X.-M., Song X., Zhang J., Du G. Performance of composite L-shaped CFST columns with inner I-shaped steel under axial compression. // Journal of Constructional Steel Research, 2020, Volume 170, article 106138.

4. Ljahovich L.S, Malinovskij A.P. Kriterij minimal'noj materialoemkosti pri usilenii sterzhnej dvutavrovogo poperechnogo sechenija i ogranichenijah na velichinu kriticheskoj sily ili pervoj sobstvennoj chastoty [Criterion of minimum material consumption with reinforcement of I-beam cross-section and restrictions on the value of the critical force or the first natural frequency]. // Vestnik TGASU, 2015, No. 5, pp. 41-50 (in Russian).

5. Ljahovich L.S., Tuhfatullin B.A., Puteeva L.E., Grigor'ev A.I. Ispol'zovanie metodov optimizacii v zadachah usilenija konstrukcij [Using optimization methods in problems of strengthening structures]. // Vestnik TGASU, 2015, No. 6, pp. 51-70 (in Russian).

6. Ляхович Л.С., Тухфатуллин Б.А. Ljahovich L.S., Tuhfatullin B.A. Proektirovanie sterzhnej postojannogo poperechnogo sechenija, minimal'noj materialoemkosti pri ogranichenijah po prochnosti na szhatie i na velichinu pervoj chastoty sobstvennyh kolebanij // «Aktual'nye problemy chislennogo modelirovanija zdanij, sooruzhenij i kompleksov». Tom 2. K 25letiju Nauchno-issledovatel'skogo centra $\mathrm{StaDiO}$ [Design of rods of constant crosssection, minimum material consumption under constraints on compressive strength and on the value of the first frequency of natural vibrations]. // "Actual problems of numerical modeling of buildings, structures and complexes", Volume 2. To the 25th anniversary of the Research Center StaDyO. Moscow, ASV Publishing House, 2016, pp. 438-443 (in Russian).

7. Lyakhovich L.S., Malinovsky A.P., Tukhfatullin B.A. Criteria for Optimal
Strengthening of Bar Flange with I-type Cross-section with Stability Constraints on the Value of the First Natural Frequency. // Procedia Engineering, 2016, Volume 153, pp. 427-433.

8. Ljahovich L.S., Malinovskij A.P., Tuhfatullin B.A. Kriterii optimal'nogo usilenija stenki sterzhnej dvutavrovogo poperechnogo sechenija pri ogranichenijah po ustojchivosti ili na velichinu pervoj sobstvennoj chastity [Criteria for the optimal reinforcement of the wall of the I-beam cross-section under constraints on stability or by the value of the first natural frequency]. // International Journal for Computational Civil and Structural Engineering, 2016, Volume 12, Issue 2, pp. 118-125 (in Russian).

9. Ljahovich L.S., Akimov P.A., Tuhfatullin B.A. Kriterii minimal'noj materialoemkosti sterzhnej prjamougol'nogo poperechnogo sechenija pri ogranichenijah po ustojchivosti ili na velichinu pervoj sobstvennoj chastoty [Criteria for the minimum material consumption of rods of rectangular crosssection with restrictions on stability or on the value of the first natural frequency]. // International Journal for Computational Civil and Structural Engineering, 2017, Volume 13, Issue 1, pp. 9-22 (in Russian).

10. Ljahovich L.S., Akimov P.A., Tuhfatullin B.A. O zadachah poiska minimuma i maksimuma v stroitel'noj mehanike [On the problems of finding the minimum and maximum in structural mechanics]. // International Journal for Computational Civil and Structural Engineering, 2017, Volume 13, Issue 2, pp. 103-124 (in Russian).

11. Lyakhovich L.S., Tukhfatullin B.A., Akimov P.A. About the solution of a structural class optimization problems. Part 1: Formulation of theoretical foundations problems of the solution procedure. // IOP Conf. Series: Materials Science and Engineering, 2018, Volume 456, 012005.

12. Lyakhovich L.S., Tukhfatullin B.A., Akimov P.A. The solution of structural class optimization problems. Part 2: Numerical 
Assessment of the Proximity of Design to Minimum Material Capacity Solution of Problem of Optimization of the Flange Width of I-Shaped Cross-Section Rods with Allowance for Stability Constraints or Constraints for the Value of the First Natural Frequency and Strength Requirements

examples. IOP Conf. Series: Materials Science and Engineering, 2018, Volume 456, 012006.

13. Lyakhovich L.S., Malinovsky A.P., Akimov P.A. Using the Criterion of the Minimum Material Capacity of Rods Under Stability Restrictions for the Case of Multiple Critical Load. // International Journal for Computational Civil and Structural Engineering, 2019, Volume 15, Issue 1, pp. 78-89.

14. Takezawa A., Yamamoto T., Zhang X., Yamakawa K., Nakano S., Kitamura $M$. An objective function for the topology optimization of sound-absorbing materials. // Journal of Sound and Vibration, 2019, Volume 443, pp. 804-819.

15. Svod pravil SP 16.13330.2017 «Stal'nye konstrukcii» (aktualizirovannaja redakcija SNiP II-23-81*) [Code of rules SP 16.13330.2017 "Steel structures" (updated edition of SNiP II-23-81*)]. Moscow, Minstroj Rossii, 2017, 140 pages (in Russian).

16. Hedli Dzh. Nelinejnoe i dinamicheskoe programmirovanie [Non-linear and dynamic programming]. Moscow, Mir, 1967, 507 pages (in Russian).

17. Хог Э., Арора Я. Hog Je., Arora Ja. Prikladnoe optimal'noe proektirovanie. Mehanicheskie sistemy i konstrukcii [Applied Optimal Design. Mechanical systems and structures]. Moscow, Mir, 1983, 479 pages (in Russian).

\section{СПИСОК ЛИТЕРАТУРЫ}

1. Лахович Л.С. Особые свойства оптимальных систем и основные направления их реализации в методах расчета сооружений. - Томск, ТГАСУ, 2009. - 372 с.

2. Li D., Paradowska A., Uy B., Wang J., Khan M. Residual stresses of box and Ishaped columns fabricated from S960 ultrahigh-strength steel. // Journal of Constructional Steel Research, 2020, Volume 166, article 105904.

3. Xiao Y., Bie X.-M., Song X., Zhang J., Du G. Performance of composite L-shaped
CFST columns with inner I-shaped steel under axial compression. // Journal of Constructional Steel Research, 2020, Volume 170, article 106138.

4. Ляхович Л.С, Малиновский А.П. Критерий минимальной материалоемкости при усилении стержней двутаврового поперечного сечения и ограничениях на величину критической силы или первой собственной частоты. // Вестник ТГАСУ, 2015, №5, c. 41-50.

5. Ляхович Л.С., Тухфатуллин Б.А., Путеева Л.Е., Григорьев А.И. Использование методов оптимизации в задачах усиления конструкций. // Вестник ТГАСУ, 2015, №6, с. 51-70.

6. Ляхович Л.С., Тухфатуллин Б.А. Проектирование стержней постоянного поперечного сечения, минимальной материалоемкости при ограничениях по прочности на сжатие и на величину первой частоты собственных колебаний // «Актуальные проблемы численного моделирования зданий, сооружений и комплексов». Том 2. К 25-летию Научноисследовательского центра СтаДиО. M.: ACB, 2016, c. 438-443.

7. Lyakhovich L.S., Malinovsky A.P., Tukhfatullin B.A. Criteria for Optimal Strengthening of Bar Flange with I-type Cross-section with Stability Constraints on the Value of the First Natural Frequency. // Procedia Engineering, 2016, Volume 153, pp. 427-433.

8. Ляхович Л.С., Малиновский А.П., Тухфатуллин Б.А. Критерии оптимального усиления стенки стержней двутаврового поперечного сечения при ограничениях по устойчивости или на величину первой собственной частоты. // International Journal for Computational Civil and Structural Engineering, 2016, Volume 12, Issue 2, pp. 118-125.

9. Ляхович Л.С., Акимов П.А., Тухфатуллин Б.А. Критерии минимальной материалоемкости стержней прямоугольного поперечного сечения при ограничениях по устойчивости или на величину 
первой собственной частоты. // International Journal for Computational Civil and Structural Engineering, 2017, Volume 13, Issue 1, pp. 9-22.

10. Ляхович Л.С., Акимов П.А., Тухфатуллин Б.А. О задачах поиска минимума и максимума в строительной механике. // International Journal for Computational Civil and Structural Engineering, 2017, Volume 13, Issue 2, pp. 103-124.

11. Lyakhovich L.S., Tukhfatullin B.A., Akimov P.A. About the solution of a structural class optimization problems. Part 1: Formulation of theoretical foundations problems of the solution procedure //IOP Conf. Series: Materials Science and Engineering. 456 (2018).

12. Lyakhovich L.S., Tukhfatullin B.A., Akimov P.A. About the solution of a structural class optimization problems. Part 1: Formulation of theoretical foundations problems of the solution procedure. // IOP Conf. Series: Materials Science and Engineering, 2018, Volume 456, 012005.

13. Lyakhovich L.S., Tukhfatullin B.A., Akimov P.A. The solution of structural class optimization problems. Part 2: Numerical examples. IOP Conf. Series: Materials Science and Engineering, 2018, Volume 456, 012006.

14. Takezawa A., Yamamoto T., Zhang X., Yamakawa K., Nakano S., Kitamura M. An objective function for the topology optimization of sound-absorbing materials. // Journal of Sound and Vibration, 2019, Volume 443, pp. 804-819.

15. Свод правил СП 16.13330.2017 «Стальные конструкции» (актуализированная редакция СНиП II-23-81*). - М.: Минстрой России, 2017. - 140 с.

16. Хедли Дж. Нелинейное и динамическое программирование. - М.: Мир, 1967. $507 \mathrm{c}$.

17. Хог Э., Арора Я. Прикладное оптимальное проектирование. Механические системы и конструкции. - М.: Мир, 1983. $-479 \mathrm{c}$.
Ляхович Леонид Семенович, академик РААСН, профессор, доктор технических наук, профессор кафедры строительной механики, Томский государственный архитектурно-строительный университет; 634003, Россия, г. Томск, Соляная пл. 2;

E-mail: 1ls@tsuab.ru

Акимов Павел Алексеевич, академик РАACH, профессор, доктор технических наук; временно исполняющий обязанности ректора Национального исследовательского Московского государственного строительного университета; профессор Департамента архитектуры и строительства Российского университета дружбы народов; профессор кафедры строительной механики Томского государственного архитектурностроительного университета; 107031, г. Москва, ул. Большая Дмитровка, д. 24, стр. 1;

тел. +7(495) 625-71-63; факс +7 (495) 650-27-31;

Email: akimov@raasn.ru,pavel.akimov@gmail.com.

Тухфатуллин Борис Ахатович, доцент, кандидат технических наук, доцент кафедры строительной механики, Томский государственный архитектурностроительный университет; 634003, Россия, г. Томск, Соляная пл. 2; e-mail: bat9203@gmail.com.

Leonid S. Lyakhovich, Full Member of the Russian Academy of Architecture and Construction Sciences, Professor, DSc, Head of Department of Structural Mechanics, Tomsk State University of Architecture and Building; 634003, Russia, Tomsk, Solyanaya St., 2;

E-mail: 1ls@tsuab.ru

Pavel A. Akimov, Full Member of the Russian Academy of Architecture and Construction Sciences, Professor, Dr.Sc.; Acting Rector of National Research Moscow State University of Civil Engineering; Professor of Department of Architecture and Construction, Peoples' Friendship University of Russia; Professor of Department of Structural Mechanics, Tomsk State University of Architecture and Building; 24, U1. Bolshaya Dmitrovka, 107031, Moscow, Russia; phone +7(495) 625-71-63;

Fax: +7 (495) 650-27-31;

E-mail: akimov@raasn.ru,pavel.akimov@gmail.com.

Boris A. Tukhfatullin, Associate Professor, Ph.D, Associate Professor of Department of Structural Mechanics, Tomsk State University of Architecture and Building; 634003, Russia, Tomsk, Solyanaya St., 2;

E-mail: bat9203@gmail.com. 